\title{
Characterization of the $\operatorname{rec} A$ gene from Pseudomonas fluorescens OE 28.3 and construction of a $\operatorname{rec} A$ mutant
}

\author{
René De Mot, ${ }^{*}$ Toon Laeremans, Geert Schoofs and Jos Vanderleyden \\ F. A. Janssens Laboratory of Genetics, Catholic University of Leuven, Willem de Croylaan 42, \\ B-3001 Heverlee, Belgium
}

(Received 25 June 1992; revised 17 August 1992; accepted 4 September 1992)

\begin{abstract}
The recA gene of Pseudomonas fluorescens OE 28.3 was isolated by complementation of the Fec ${ }^{-}$phenotype of recombinant lambda EMBL3 phages in a RecA ${ }^{-}$Escherichia coli strain. The subcloned rec $A$ restored resistance to UV and methyl methanesulphonate (MMS) exposure in $r e c A$ mutants of $E$. coli. DNA sequence analysis showed that the coding region of the $P$. fluorescens gene, specifying a protein of 352 amino acid residues, was preceded by an SOS box highly similar to those of Pseudomonas aeruginosa and Azotobacter vinelandii. The deduced amino acid sequence displayed highest homology to the RecA proteins from $P$. aeruginosa $(87.8 \%$ identity) and $A$. vinelandii $(84.3 \%$ identity). In both the regulatory region and the structural gene, a relatively high degree of sequence divergence from the Pseudomonas cepacia gene was observed. A mutant of $P$. fluorescens was constructed by inserting a kanamycin resistance cassette into its $\operatorname{rec} A$ gene. This mutant exhibited an increased sensitivity to UV irradiation and MMS, and was strongly impaired in homologous recombinational activity.
\end{abstract}

\section{Introduction}

Certain soil bacteria occurring in the rhizosphere of crop plants exert a beneficial effect on the development of their hosts by either a direct (hormone production) or an indirect (biocontrol of soil phytopathogens) mechanism (Lugtenberg et al., 1991). In view of the agronomic potential of inocula based on such plant-growthpromoting rhizobacteria (PGPR) for environmentally friendly cropping practices, interest in these bacteria has increased steadily during the last decade, providing new insights into the mechanisms of growth promotion and root colonization. In temperate soils, the fluorescent Pseudomonas species $P$. fluorescens and $P$. putida represent the major PGPR.

Recently, we identified a root adhesin in the wheat rhizobacterium P. fluorescens OE 28.3 (De Mot \& Vanderleyden, 1991), and characterized the correspond-

*Author for correspondence. Tel. 3216220921 ; fax. 3216220761 ; e-mail KIAAA31@BLEKUL21.

Abbreviations: MMS, methyl methanesulphonate; PGPR, plantgrowth-promoting rhizobacteria.

The nucleotide sequence data reported in this paper have been submitted to GenBank and have been assigned the accession number M96558. ing $o p r F$-like gene, encoding a major outer-membrane protein (De Mot et al., 1992). Studying the role of this adhesin in root colonization by PGPR requires gene manipulation in $P$. fuorescens. For this purpose, the availability of a recombination-deficient mutant is essential.

The $\operatorname{rec} A$ gene product plays a pivotal role in bacterial homologous recombination, as well as in other cellular processes such as DNA repair (Miller \& Kokjohn, 1990; Roca \& Cox, 1990). Within the Pseudomonas group, recA mutants have been characterized for the opportunistic human pathogen $P$. aeruginosa (Früh et al.. 1983) and for the foliar pathogen $P$. syringae (Willis et al., 1988; Barbé et al., 1991), both belonging to the same rRNA cluster as $P$. fluorescens (group I). In addition. the recA genes of $P$. aeruginosa (Sano \& Kageyama, 1987) and of the rRNA group II species $P$. cepacia (Nakazawa et al., 1990) have been sequenced.

In this paper we describe the molecular cloning and sequencing of the rec $A$ gene from $P$. fluorescens $\mathrm{OE} 28.3$, and the construction and characterization of a RecAdeficient strain for this wheat isolate.

\section{Methods}

Bacterial strains, plasmids, phages, media and growth conditions. The bacterial strains, plasmids and phages used in this work are listed in Table 1. E. coli and P. fuorescens strains were grown in Luria broth 
Table 1. Bacterial strains, plasmids and phages

\begin{tabular}{|c|c|c|}
\hline \multicolumn{3}{|l|}{ P. fuorescens } \\
\hline OE 28.3 & Isolate from wheat rhizosphere & De Mot \& Vanderleyden (1991) \\
\hline \multicolumn{3}{|l|}{ E. coli } \\
\hline RR1 & proA2 lac Y1 hsdS20 endA rpsL20 ara-14 galK2 xyl-5 mtl-1 supE44 & \multirow{2}{*}{ Sambrook et al. (1989) } \\
\hline $\mathrm{HB} 101$ & $\operatorname{rec} A 13$ mutant of strain $\mathrm{RR} 1$ & \\
\hline S17-1 & $\mathrm{F}^{-}$rec $A$ hsdR with modified RP4 in chromosome & Simon et al. (1983) \\
\hline \multicolumn{3}{|l|}{ Plasmids } \\
\hline pKN3 & pBR322 with $P$. cepacia rec $A$ gene & Nakazawa et al. (1990) \\
\hline pSUP102 & $\mathrm{Cm}^{\mathrm{r}} \mathrm{Tc}^{\mathrm{r}} \mathrm{Mob}^{+}$ & Simon et al. (1983) \\
\hline pUKA 800 & pUC8 with $\mathrm{Km}^{\mathrm{r}}$ GenBlock from pUC-4K (Pharmacia) & This laboratory \\
\hline pFAJ2006 & pUC19 with $P$. fluorescens $\mathrm{OE} 28.3 \mathrm{rec} A$ on $3.8 \mathrm{~kb}$ EcoRI fragment & \multirow{2}{*}{ This paper } \\
\hline pFAJ 2084 & pSUP102 with randomly cloned $5 \mathrm{~kb} E c o \mathrm{RI}$ fragment from strain $\mathrm{OE} 28.3$ ) & \\
\hline \multicolumn{3}{|l|}{ Lambda phages } \\
\hline$\lambda \mathrm{FAJ} 2001$ & ¿EMBL3 carrying $P$. fluorescens OE $28.3 \mathrm{opr} F$ gene & De Mot et al. (1992) \\
\hline$\lambda \mathrm{FAJ} 2003$ & ¿EMBL3 carrying $P$. fluorescens $\mathrm{OE} 28.3 \mathrm{rec} A$ gene & This paper \\
\hline
\end{tabular}

(LB) medium $\left(37^{\circ} \mathrm{C}\right)$ and trypticase soy broth (TSB) medium $\left(30^{\circ} \mathrm{C}\right)$, respectively. For solid media, $15 \mathrm{~g}$ agar $\mathrm{l}^{-1}$ was added. In conjugation experiments, M9 minimal medium was used for selection of $P$. fuorescens transconjugants. Antibiotics were used at the following concentrations: ampicillin $100 \mu \mathrm{g} \mathrm{ml} l^{-1}$, kanamycin $50 \mu \mathrm{g} \mathrm{ml}^{-1}$, chloramphenicol $25 \mu \mathrm{g} \mathrm{ml}^{-1}$, tetracycline $10 \mu \mathrm{g} \mathrm{ml}^{-1}$. $\alpha$-Complementation of $l a c Z$ was detected on LB plates supplemented with 5-bromo4-chloro-3-indolyl $\beta$-D-galactopyranoside and isopropyl $\beta$-D-thiogalactopyranoside at $20 \mu \mathrm{g} \mathrm{ml}^{-1}$. Phage-infected $E$. coli cells were plated as described by Frischauf et al. (1987). Cell doubling times were estimated from the increase in $\mathrm{OD}_{600}$ during aerobic incubation in TSB medium on a rotary shaker (200 r.p.m.).

Determination of sensitivity to $U V$ irradiation and methyl methanesulphonate (MMS). E. coli or P. fluorescens cells were grown in LB $\left(37^{\circ} \mathrm{C}\right)$ or TSB $\left(30^{\circ} \mathrm{C}\right)$ to an $\mathrm{OD}_{600}$ of about 1 . The cells were washed

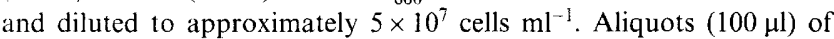
several tenfold dilutions were spread in triplicate on LB or TSB plates. When testing MMS sensitivity, the media contained $0 \cdot 1,0 \cdot 5,1$ or $2 \mathrm{mM}$ of this DNA-methylating agent. Different doses of UV radiation $(312 \mathrm{~nm})$, ranging from 50 to $200 \mathrm{~J} \mathrm{~m}^{-2}$, were applied to the plated cells using a transilluminator. Plates were incubated overnight (or longer when delayed growth was observed in the presence of MMS) at $37^{\circ} \mathrm{C}$ (E. coli) or $30^{\circ} \mathrm{C}$ ( $P$. fluorescens). The level of resistance was calculated from the relative number of surviving cells using MMS-free or nonirradiated plates as a control.

DNA methods and sequence analysis. E. coli plasmids were extracted using the alkaline lysis method, whereas total DNA from Pseudomonas strains was isolated with the cetyltrimethylammonium bromide procedure (Sambrook et al., 1989). Phage DNA was prepared according to Lockett (1990). Double-stranded DNA sequencing of pUC19 subclones was carried out using the AutoRead Sequencing Kit (Pharmacia-LKB) on an automated sequencer (A.L.F., PharmaciaLKB). Sequence data were processed using the ASSEMGEL program (PC Gene, IntelliGenetics). The PC Gene software was also used for sequence comparison of deduced proteins by pairwise (PALIGN) or multiple (CLUSTAL) alignments.

Southern hybridization. Genomic or plasmid DNA cut with appropriate restriction endonucleases was transferred by capillary blotting to Hybond-N membranes (Amersham) after agarose electrophoresis. The following probes were isolated by preparative electrophoresis and non-radioactively labelled with the random priming method (DIG chemiluminescent system, Boehringer Mannheim): the $1.2 \mathrm{~kb} E c o \mathrm{RI}$ fragment from $\mathrm{pKN} 3$ carrying most of the $P$. cepacia recA gene; the $1.25 \mathrm{~kb}$ HindIII fragment containing the kanamycin resistance cassette from pUKA 800 ; and the $1.8 \mathrm{~kb} E \mathrm{c}^{\circ} \mathrm{RI}-\mathrm{BamHI}$ fragment from pSUP102. The non-radioactive hybridization was carried out as recommended by the manufacturer using a hybridization temperature of $68{ }^{\circ} \mathrm{C}$ and final washing in $0.1 \times \mathrm{SSC}$ plus $0.1 \%$ SDS. SSC $(1 \times)$ contains $0 \cdot 15 \mathrm{M}-\mathrm{NaCl}$ and $15 \mathrm{~mm}$-sodium citrate at $\mathrm{pH} 7 \cdot 0$.

Homologous recombination. Following random cloning of genomic EcoRI fragments from $P$. fluorescens OE 28.3 in pSUP102, two clones with inserts of $4 \mathrm{~kb}$ (pFAJ2083) and $5 \mathrm{~kb}$ (pFAJ2084) were selected to assess the homologous recombinational activity in strains OE 28.3 and FAJ2025 by the method of Selbitschka et al. (1991). The recombinant plasmids were introduced into these Pseudomonas strains by biparental conjugation using $E$. coli $\mathrm{S} 17-1$ as a donor. The frequency of appearance of tetracycline-resistant transconjugants per acceptor cell was determined.

\section{Results and Discussion}

Cloning of the rec $A$ gene

A previously constructed genomic library of $P$. fluorescens OE 28.3 in lambda EMBL3 (De Mot et al., 1992) was plated on E. coli HB101 cells. Ten plaque- 


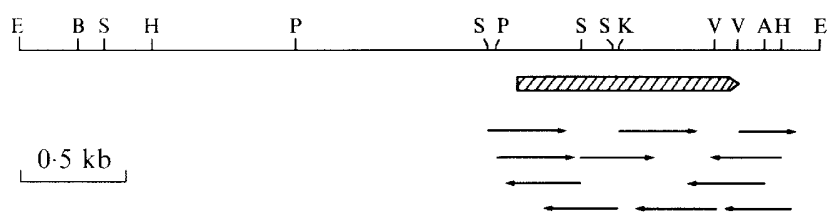

Fig. 1. Restriction map of the $3.8 \mathrm{~kb}$ Eco RI fragment of $P$. fluorescens OE 28.3 carrying the $r e c A$ gene. The sequencing strategy is outlined by the arrows and the position of the open reading frame is shown. Restriction sites are indicated as follows: A, Aval; B, BamHI; E, EcoRI; H, HindIII; K, KpnI; P, PstI; S, SalI; V, EcoRV.

forming recombinant phages were purified by repeated plating and finally checked for lytic activity on other $\mathrm{RecA}^{-}$strains of E. coli (DH1, DH5 $\left.\alpha\right)$. The identical SalI restriction patterns of these clones indicated that all of them contained the same insert. The $P$. cepacia rec $A$ gene was used to probe a Southern blot of DNA from a selected phage ( $\lambda$ FAJ2003) restricted with several endonucleases. For a $3.8 \mathrm{~kb}$ EcoRI and a $3 \mathrm{~kb} H$ indIII fragment strong signals were obtained. These fragments were subcloned in pUC19 to generate pFAJ2006 and pFAJ2009, respectively.

A recombinant phage, containing an unrelated DNA

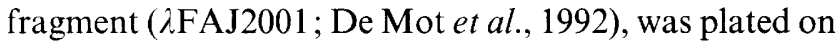
E. coli $\mathrm{DH} 5 \alpha$ cells containing pFAJ2006 or pFAJ2009. Whereas $\lambda \mathrm{FAJ} 2001$ was incapable of lytic growth on strain DH $5 \alpha$ (or other RecA ${ }^{-}$strains such as HB101 and $\mathrm{DH} 1$ ), its plaque-forming ability was restored by the presence of the recombinant plasmids, intermediate to the level obtained with $\operatorname{Rec}^{+}$strains. These observations indicated that a functional $\operatorname{rec} A$ gene had been cloned. This was further substantiated by the enhanced UV resistance and reduced MMS sensitivity of $\mathrm{RecA}^{-}$E. coli hosts carrying pFAJ2006 or pFAJ2009, approaching the levels attained by the $\operatorname{RecA}^{+}$strain RR1 (results not shown).

Thus, the rec $A$ gene from $P$. fluorescens was isolated from a phage library by interspecific complementation of the $\mathrm{Fec}^{-}$phenotype of the recombinant phage in E. coli. Recently, this approach proved equally successful for the recA gene from Rhizobium phaseoli (Michiels et al., 1991; Martínez-Salazar et al., 1991). Whereas most recA genes have been identified by the ability to confer resistance to DNA damaging agents when cloned in $\operatorname{RecA}^{-} E$. coli strains, the direct screening of a phage library on a RecA host provides a straightforward alternative method for their identification.

\section{Nucleotide sequence of the rec $A$ gene}

Physical mapping of the inserts from pFAJ2006 and pFAJ2009 showed that the EcoRI fragment encompassed the HindIII fragment (Fig. 1). The approximate position of the rec $A$ gene within the latter fragment was established by Southern hybridization. For the region of interest, several overlapping pUC19 subclones were isolated and sequenced as shown in Fig. 1.

The region sequenced (1444 bp, $\mathrm{G}+\mathrm{C}$ content $57 \%$ ) revealed one large open reading frame spaced five nucleotides from a typical Shine-Dalgarno sequence. GAGGA (Fig. 2). Further upstream of the coding region (positions 100-119), the sequence TACTGTCTACTTATACAGGT was identified as a putative SOS box, corresponding to the E. coli consensus sequence CTG$\mathrm{N}_{10}$-CAG that enables binding of the LexA repressor protein (Walker, 1987). This $P$. fluorescens SOS box most closely resembles those reported for $P$. aeruginosa and Azotobacter vinelandii (Fig. 3). Only one single base out of 20 is different between these three species. Higher sequence divergence is seen for another Pseudomonas species, $P$. cepacia, five and six bases being different from $P$. aeruginosa and $P$. fluorescens, respectively. Surprisingly, the $P$. cepacia SOS box shows closer resemblance to the one from Bordetella pertussis (differences at four positions only).

Partially overlapping with the putative repressorbinding region of $P$. fluorescens rec $A$, a putative $\sigma^{70}$-type promoter sequence is found between positions 89-116 (Fig. 3). This TTGTGG-N 16 -TATACA sequence is similar to known $\sigma^{70}$-dependent Pseudomonas promoters (Deretic et al., 1989). In the regulatory region of the $\mathrm{rec} A$ gene from Pseudomonas aeruginosa, the sequence CTGTGG- $\mathrm{N}_{16}$-TATACA is present, differing only at the first position (Sano \& Kageyama, 1987). Despite the high homology between their SOS boxes (covering the -10 promoter region in both fluorescent Pseudomonas species), no obvious Pseudomonas-like -35 region appears to occur in $A$. vinelandii (Venkatesh \& Das, 1992). However, a related $-35 /-10$ sequence (TTGCAC- $\mathrm{N}_{15}$-TATACA) partially overlaps with the SOS box from $P$. cepacia (Nakazawa et al., 1990) and is reminiscent of the motif found in $B$. pertussis: TGGCAC-N ${ }_{15}$-AGTACA (Favre \& Viret, 1990). A promoter region overlapping with a potential LexA binding site also exists in Vibrio anguillarum (Tolmasky et al., 1992).

These observations indicate that a LexA-like mediated SOS response is probably operative in several bacteria outside the Enterobacteriaceae (Zhao \& McEntee, 1990). including fluorescent Pseudomonas species. Actually, this was recently shown by introducing a broad-host-range plasmid, carrying an E. coli rec $A-l a c Z$ operon fusion. into various Gram-negative bacteria (Fernandez de Henestrosa et al., 1991). Repression and induction of rec $A$ transcription in, respectively, the absence and presence of the DNA damaging agent mitomycin $\mathrm{C}$ was demonstrated in, among other bacteria, $P$. syringae, $P$. 
GTCGACAAACGGTAAAGGCCGCGCTGGAGGGCTTGTTGCGACGAGCTGCAGCAGAAATCGAAAATCAGGGGT

AGGCGATCCCGGATCTTTGTGGAACAAPACTGTCTACTTATACAGGT GTTGGCCGTCAGCTTATTGATTACG TGAGGACTTTAATGGACGACAACAAGAAGAAAGCCTTGGCTGCGGCCCTGGGTCAGATCGAACGTCAATTCG

$\begin{array}{lllllllllllllllllllllllll}\mathbf{S} & \mathbf{G} & \mathbf{K} & \mathbf{T} & \mathbf{T} & \boldsymbol{I} & \mathbf{T} & \boldsymbol{L} & \mathbf{S} & \mathbf{V} & \boldsymbol{I} & \mathbf{A} & \boldsymbol{Q} & \mathbf{A} & \boldsymbol{Q} & \mathbf{K} & \mathbf{M} & \mathbf{G} & \mathbf{A} & \mathbf{T} & \mathbf{C} & \mathbf{A} & \mathbf{F} & \mathbf{V}\end{array}$ ACGCCGAGCACGCCCTTGACCCGGAATACGCCGGTAAGCTGGGCGTCAACGTTGACGACCTGCTGGTTTCCC

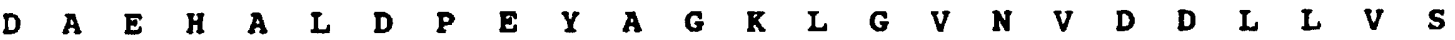
AGCCGGACACCGGTGAGCAAGCCCTGGAAATCACCGACATGCTGGTGCGCTCCAACGCCATCGACGTGATCG

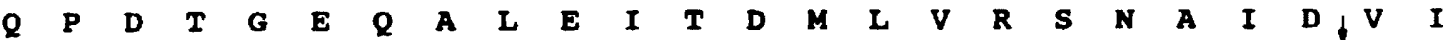
TGGTCGACTCCGTGGCTGCCCTGGTACCGAAAGCTGAAATCGAAGGCGAAATGGGCGACATGCACGTGGGCC $\begin{array}{llllllllllllllllllllllll}\mathbf{V} & \mathbf{V} & \mathbf{D} & \mathbf{S} & \mathbf{V} & \mathbf{A} & \mathbf{A} & \mathbf{L} & \mathbf{V} & \mathbf{P} & \mathbf{K} & \mathbf{A} & \mathbf{E} & \mathbf{I} & \mathbf{E} & \mathbf{G} & \mathbf{E} & \boldsymbol{M} & \mathbf{G} & \mathbf{D} & \mathbf{M} & \mathbf{H} & \mathbf{V} & \mathbf{G}\end{array}$ TGCAAGCCCGCCTGATGTCCCAGGCGCTGCGTAAAATTACCGGTAACATCAAGAACGCCAACTGCCTGGTGA $\begin{array}{llllllllllllllllllllllll}\mathbf{L} & \mathbf{Q} & \mathbf{A} & \mathbf{R} & \mathbf{L} & \mathbf{M} & \mathbf{S} & \mathbf{Q} & \mathbf{A} & \mathbf{L} & \mathbf{R} & \mathbf{K} & \mathbf{I} & \mathbf{T} & \mathbf{G} & \mathbf{N} & \mathbf{I} & \mathbf{K} & \mathbf{N} & \mathbf{A} & \mathbf{N} & \mathbf{C} & \mathrm{L} & \mathbf{V}\end{array}$ TCTTCATCAACCAGATCCGTATGAAGATCGGCGTAATGTCGGCAGCCCGGAAACCACTACCGGTGGTAACG $\begin{array}{llllllllllllllllllllllll}I & \mathbf{F} & \mathbf{I} & \mathbf{N} & \mathbf{Q} & \mathbf{I} & \mathbf{R} & \mathbf{M} & \mathbf{K} & \mathbf{I} & \mathbf{G} & \mathbf{V} & \mathbf{M} & \mathbf{F} & \mathbf{G} & \mathbf{S} & \mathbf{P} & \mathbf{E} & \mathbf{T} & \mathbf{T} & \mathbf{T} & \mathbf{G} & \mathbf{G} & \mathbf{N}\end{array}$ CGCTGAAGTTCTACGCTTCGGTCCGTCTGGACATCCGCCGTACCGGCGCGGTGAAGGAAGGTGACGAAGTTG $\begin{array}{llllllllllllllllllllllll}\mathbf{A} & \mathbf{L} & \mathbf{K} & \mathbf{F} & \mathbf{Y} & \mathbf{A} & \mathbf{S} & \mathbf{V} & \mathbf{R} & \mathbf{L} & \mathbf{D} & \mathbf{I} & \mathbf{R} & \mathbf{R} & \mathbf{T} & \mathbf{G} & \mathbf{A} & \mathbf{V} & \mathbf{R} & \mathbf{E} & \mathbf{G} & \mathbf{D} & \mathbf{E} & \mathbf{V}\end{array}$ TTGGTAGCGAAACTCGCGTTAAAGTCGTGAAGAACAAGGTCGCTCCGCCTTTCCGTCAGGCAGAGTTCCAGA $\begin{array}{llllllllllllllllllllllll}\mathbf{V} & \mathbf{G} & \mathbf{S} & \mathbf{E} & \mathbf{T} & \mathbf{R} & \mathbf{V} & \mathbf{K} & \mathbf{V} & \mathbf{V} & \mathbf{K} & \mathbf{N} & \mathbf{K} & \mathbf{V} & \mathbf{A} & \mathbf{P} & \mathbf{P} & \mathbf{F} & \mathbf{R} & \mathbf{Q} & \boldsymbol{A} & \mathbf{E} & \mathbf{F} & \mathbf{Q}\end{array}$ TTCTCTACGGCAAGGGTATCTACCTGAACGGCGAGATGATTGACCTGGGCGTACTGCACGGTTTCGTCGAGA

1008 $\begin{array}{llllllllllllllllllllllll}I & \mathbf{L} & \mathbf{I} & \mathbf{G} & \mathbf{K} & \mathbf{G} & \mathbf{I} & \mathbf{Y} & \mathbf{L} & \mathbf{N} & \mathbf{G} & \mathbf{E} & \mathbf{M} & \mathbf{I} & \mathbf{D} & \mathbf{L} & \mathbf{G} & \mathbf{V} & \mathbf{L} & \mathbf{H} & \mathbf{G} & \mathbf{F} & \mathbf{V} & \mathbf{E}\end{array}$ AGTCCGGTGCCTGGTATGCCTACAACGGCAGCAAGATCGGTCAGGGCAAGGCCAACTCGGCCAAGTTCCTGG

1080 $\begin{array}{llllllllllllllllllllllll}\mathbf{K} & \mathbf{S} & \mathbf{G} & \mathbf{A} & \mathbf{W} & \mathbf{Y} & \mathbf{A} & \mathbf{Y} & \mathbf{N} & \mathbf{G} & \mathbf{S} & \mathbf{K} & \mathbf{I} & \mathbf{G} & \boldsymbol{Q} & \mathbf{G} & \boldsymbol{K} & \mathbf{A} & \mathbf{N} & \mathbf{S} & \mathbf{A} & \mathbf{K} & \mathbf{F} & \boldsymbol{L}\end{array}$ CAGACAACCCGGATATCGTCGCCACGCTTGAGAAGCAGATTCGCGACAAGCTGCTGACCCCAGCGCCAGACG $\begin{array}{llllllllllllllllllllllll}\mathbf{A} & \mathbf{D} & \mathbf{N} & \mathbf{P} & \mathbf{D} & \mathbf{I} & \mathbf{V} & \mathbf{A} & \mathbf{T} & \mathbf{L} & \mathbf{E} & \mathbf{K} & \mathbf{Q} & \mathbf{I} & \mathbf{R} & \mathbf{D} & \mathbf{K} & \mathbf{L} & \mathbf{L} & \mathbf{T} & \mathbf{P} & \mathbf{A} & \mathbf{P} & \mathbf{D}\end{array}$ TGAAAGCTGCCGCCAACCGCGAGCCGGTTGAAGAAGTGGAAGAAGCTGACACTGATATCTGAAGCAAACGAT $\begin{array}{lllllllllllllllllllll}\mathbf{V} & \mathbf{K} & \mathbf{A} & \mathbf{A} & \mathbf{A} & \mathbf{N} & \mathbf{R} & \mathbf{E} & \mathbf{P} & \mathbf{V} & \mathbf{E} & \mathbf{E} & \mathbf{V} & \mathbf{E} & \mathbf{E} & \mathbf{A} & \mathbf{D} & \mathbf{T} & \mathbf{D} & \mathbf{I} & \text { * }\end{array}$ GACTGTGGTACTGGATACACTCGTCGCCGTTCGGCGCACCGCGATGGACCTGCTCGCTCGCCGCGAGCATGG TCGAGTCGAGCTGACGCGTAAACTGCGTCAGCGCGGTGCAGAGCCCGAGATGATCGAAACAGCCCTCGACCG TTTGACGGAAGAGGGGCTGCTTTCCGAAGCCCGCTATCTTGAAAGCTTTGTTTCCTACCGCGCGCGCTCCGG CTAT

Fig. 2. DNA sequence and deduced amino acid sequence of the $P$. fluorescens rec $A$ gene. The putative ribosome binding site and downstream potential stem-loop structures are underlined. In the $5^{\prime}$ regulatory region, the SOS sequence is boxed and the $-35 /-10$ regions of a putative $\sigma^{70}$-type of promoter are printed in italic type. The arrow points out the unique $B b r P I$ site (CACGTG) used for insertional inactivation of the gene.

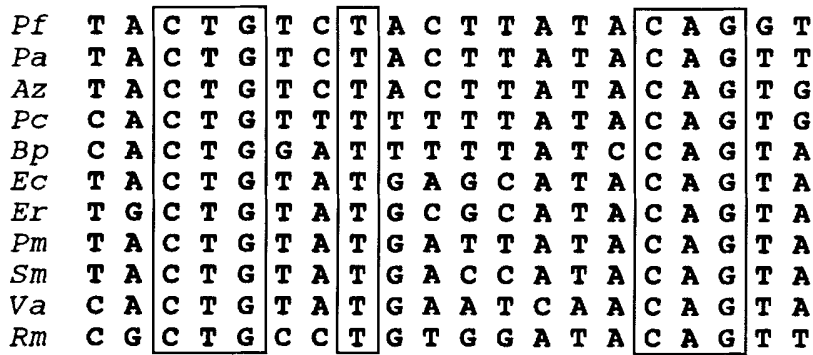

Fig. 3. Alignment of the LexA operator sequence, preceding the Escherichia coli recA gene $(E c)$, with the putative SOS regulatory elements from Azotobacter vinelandii $(A z)$, Bordetella pertussis $(B p)$, Erwinia carotovora (Er), Proteus mirabilis (Pm), Pseudomonas aeruginosa $(P a), P$. cepacia $(P c), P$. fluorescens $(P f)$, Rhizobium meliloti $(R m)$, Serratia marcescens $(S m)$ and Vibrio anguillarum $(V a)$ The corresponding sequences of Shigella flexneri (identical to E. coli) and of Proteus vulgaris (identical to P. mirabilis) are not shown. Boxed regions indicate perfect base conservation throughout currently recognized SOS sequences (Favre \& Viret, 1990; Selbitschka et al., 1991; Tolmasky et al., 1992; Venkatesh \& Das, 1992). 
Fig. 4. Dendrogram showing relative distances between RecA proteins, based on multiple sequence alignment (CLUSTAL program) of the proteins from Acholeplasma laidlawii (Al), Anabaena variabilis $(A v)$, Aquaspirillum magnetotacticum $($ Am), Azotobacter vinelandii (Az), Bacillus subtilis $(B s)$, Bacteroides fragilis $(B f)$, Bordetella pertussis $(B p)$, Erwinia carotovora (Er), Escherichia coli (Ec), Methylobacillus flagellatum (Mf), Neisseria gonorrhoeae $(\mathrm{Ng})$, Proteus mirabilis $(\mathrm{Pm}), \mathrm{Pr}$. vulgaris $(P v)$, Pseudomonas aeruginosa $(P a), P$. cepacia $(P c), \quad P$. fluorescens $(P f)$, Rhizobium leguminosarum $(R l), R$. phaseoli $(R p), R$. meliloti $(R m)$, Serratia marcescens $(S m)$, Synechococcus sp. (Sy), Thiobacillus ferrooxidans (Tf) and Vibrio anguillarum $(\mathrm{Va})$. The Shigella flexneri sequence (not shown) is identical to RecA of E. coli. The respective percentages of residues identical with the $P$. fuorescens protein as deduced from pairwise alignments, are indicated on the right. References to sequences not included in the review by Roca \& Cox (1990) are: Favre \& Viret (1990), Fyfe \& Davies (1990), Gomelsky et al. (1990), Goodman \& Woods (1990), Nakazawa et al. (1990), Michiels et al. (1991), Selbitschka et al. (1991), Dybvig \& Woodard (1992), Tolmasky et al. (1992) and Venkatesh \& Das (1992).

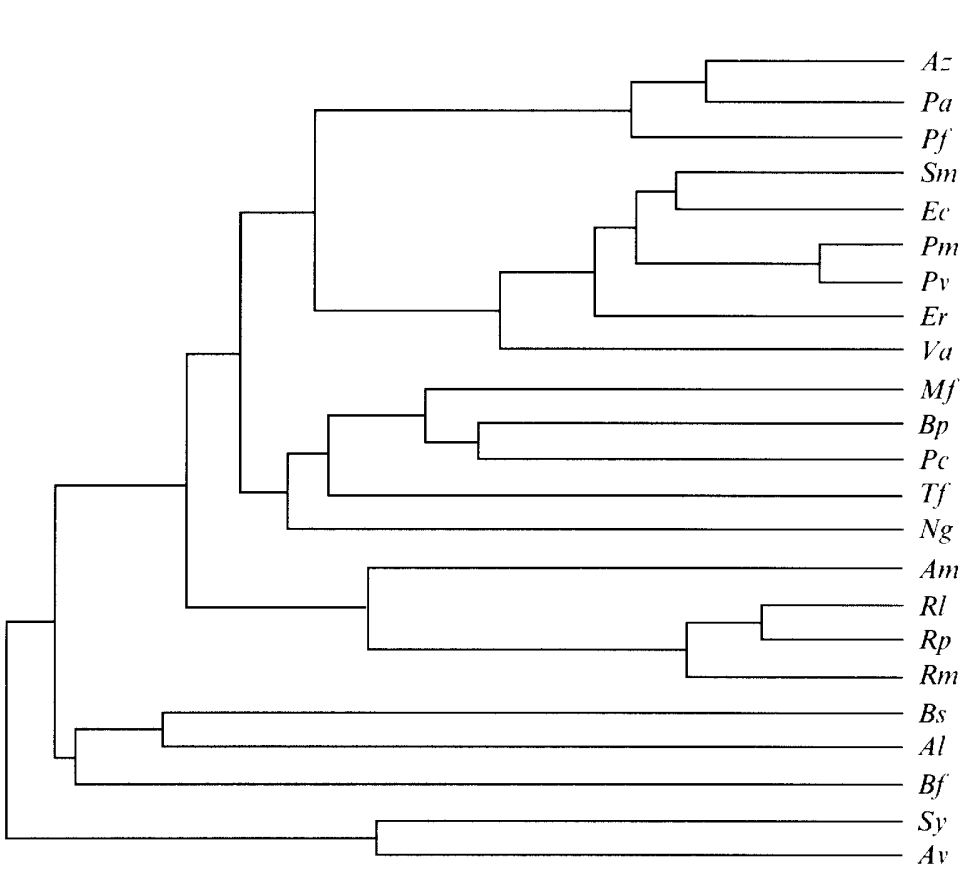

Similarity $(\%)$ $84 \cdot 3$ 87.8 $100 \cdot 0$ $70 \cdot 9$ $69 \cdot 5$ $70 \cdot 3$ $69 \cdot 5$ $67 \cdot 8$ 69.5 $72 \cdot 9$ $66 \cdot 6$ 69.8 $67 \cdot 2$ $66 \cdot 4$ $62 \cdot 7$ $65 \cdot 5$ $64 \cdot 7$ $66 \cdot 1$ $57 \cdot 5$ 56.4 $56 \cdot 4$ $56 \cdot 3$ $59 \cdot 3$ aeruginosa and $P$. putida. From the latter two species, lexA-like genes have now been cloned (Calero et al., 1991). In Bacillus subtilis, the putative repressor of the SOS-like SOB regulon recognizes an operator sequence different from the LexA box of E. coli (Cheo et al., 1991).

\section{Deduced amino acid sequence of $\operatorname{Rec} A$}

The open reading frame in Fig. 2 encodes a protein of 352 amino acids with a calculated molecular mass of $37634 \mathrm{Da}$. Since the comparison of RecA sequences by Roca \& Cox (1990), several new rec $A$ genes have been sequenced, including those from some species belonging to quite distant genera such as Bacteroides and Acholeplasma. For a detailed comparison of $P$. fluorescens RecA with the currently known corresponding proteins from other Eubacteria, a multiple sequence alignment was carried out for 24 sequences in order to construct a RecA-based dendrogram (Fig. 4). The actual sequence alignment is shown in Fig. 5. In these alignments, the amino acid sequence deduced from the Mycobacterium tuberculosis rec $A$ locus is not included since it contains a large central non-homologous region of 440 residues (Davis et al., 1991).

Apparently, the extent of sequence homology among RecA proteins reflects well the phylogenetic relationship of the respective bacteria. Indeed, nicely separated clusters were generated for enterobacteria, rhizobia and cyanobacteria. The representatives of Gram-positive bacteria and the related mycoplasmas, as well as of the bacteroides are also well separated (Fig. 4).

The $P$. fluorescens RecA is most similar to the $P$. aeruginosa protein: $87.8 \%$ identical residues as compared to $69.5 \%$ with $E$. coli RecA (Fig. 4). Surprisingly, RecA from Azotobacter vinelandii shares $84.3 \%$ of its residues with the $P$. fluorescens protein. As can be deduced from their clustering in Fig. 4, homology between the Azotobacter species and $P$. aeruginosa is even higher ( $89 \cdot 2 \%$ identical amino acids). As mentioned above, this high level of sequence conservation is extended to the upstream regulatory region of these three genes, namely their putative SOS boxes. A substantially lower degree of similarity exists between the $P$. fluorescens and $P$. cepacia RecA proteins $(69.8 \%$ identity). Conversely, $P$. cepacia RecA shows much better alignment with the Bordetella pertussis protein (Fig. 4). The RecA proteins from these species possess as much as $81.2 \%$ identical amino acids. As discussed earlier, the rather unexpected clustering of these Bordetella and Pseudomonas species is again reflected in a high degree of similarity of the respective regulatory regions. These observations add to the uncertainty about the current taxonomic position of $P$. cepacia within the large Pseudomonas group.

As more $\operatorname{rec} A$ genes are sequenced, the extremely high degree of sequence conservation among their gene products ( $23 \%$ overall identity) becomes more striking. For instance, $P$. fluorescens RecA has over $56 \%$ residues 


$$
\begin{aligned}
& A z \\
& P a \\
& P f \\
& S m \\
& E C \\
& P r \\
& P V \\
& E r \\
& V a \\
& M f \\
& B p \\
& P C \\
& T f \\
& N g \\
& A m \\
& R I \\
& R p \\
& R m \\
& B S \\
& A I \\
& B f \\
& S y \\
& A V
\end{aligned}
$$

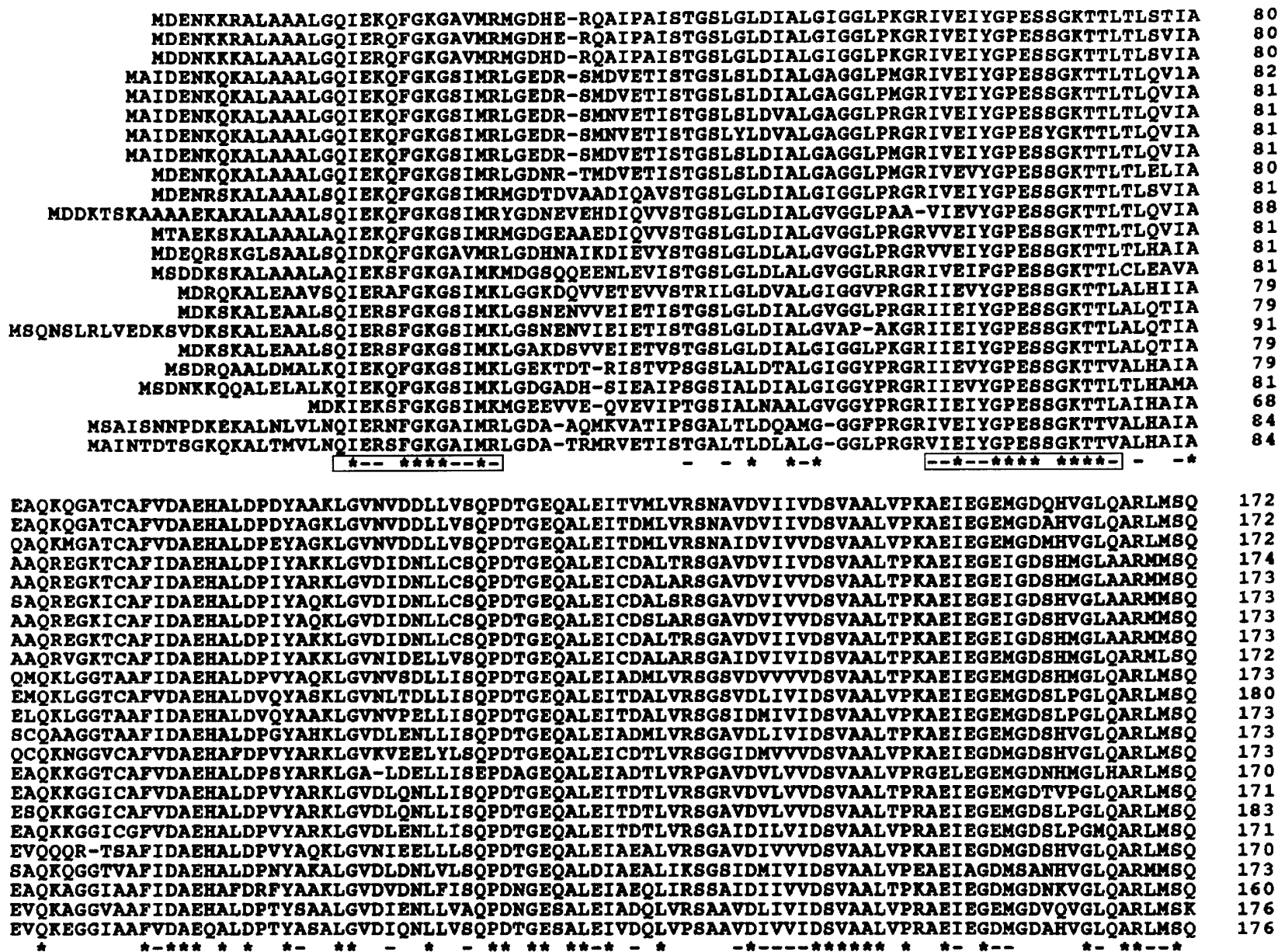

Fig. 5. For legend see opposite.

in common with distant species such as Synechococcus sp. and Acholeplasma laidlawii (Fig. 4). In view of these data, it is unlikely that the sequence reported for Vibrio cholerae (Ghosh et al., 1992) represents its RecA protein, sharing only $13 \%$ of its amino acids with the protein from the rather closely related $E$. coli. Also, no significant alignment with $V$. anguillarum RecA could be achieved. Therefore, the $V$. cholerae sequence was excluded from the multiple alignment and dendrogram building in this paper.

Specific parts of the RecA proteins are most highly conserved (Fig. 5). For the ATP-binding domain proposed by Higgins et al. (1986), the consensus sequence [I/V][I/V]E[I/V][Y/F]GPES[S/Y]GKTT[L/V], corresponding to amino acids 60-74 of $P$. fluorescens RecA can now be deduced. Another contiguous, conserved portion is found between residues 202 and 222, reflecting the consensus $[\mathrm{F} / \mathrm{Y}] \mathrm{G}[\mathrm{N} / \mathrm{S}] \mathrm{PE}[\mathrm{T} / \mathrm{V}] \mathrm{T}[\mathrm{T} / \mathrm{P}] \mathrm{G}[\mathrm{G} / \mathrm{A}] \mathrm{XA}$ $\mathrm{LKF}[\mathrm{Y} / \mathrm{F}][\mathrm{A} / \mathrm{S}] \mathrm{SVR}[\mathrm{L} / \mathrm{M}]$. It is located in a spacer between two core elements of the proposed threedimensional structure of $E$. coli RecA (Miller \&
Kokjohn, 1990). The present compilation of data favours the continued use of part of this sequence (AL ... VR) as a RecA signature (Bairoch, 1991). High sequence conservation is also evident in the $\mathrm{N}$-terminal domain with the consensus sequence $[Q / K] I[D / E][K / R] X[F / Y]-$ GKG[A/S][V/I]M[K/R] (residues $15-27$ of $P$. fuorescens RecA), which is essential for interaction with single-stranded DNA and for filament formation (Miller \& Kokjohn, 1990). On the other hand, the C-terminal region of $P$. fluorescens RecA shows little sequence homology with its counterparts from other bacteria (Fig. 5). However, it is enriched in acidic residues (7 in a stretch of 13 amino acids), as are most other RecA proteins (Roca \& Cox, 1990).

In the deduced consensus sequences, the corresponding regions of the anomalously long RecA from Mycobacterium tuberculosis have been included (Davis $e t$ al., 1991). Recently, short internal rec $A$ fragments from several Gram-positive bacteria and mycoplasmas were isolated by using the polymerase chain reaction and sequenced (Duwat et al., 1992; Dybvig et al., 1992). 
ALRKI TGMIQNANCLVIF INQIRMKIGVUTGNPETTTGANALKFYASVRLDIRRTGAVRESDEV-IGSETRVKVVKNKVAPPFRQAEFQILY ALRRITGNIKNANCLVIFINOIRMKI GVMPGNP ETTTGGNALKFYASVRLDIRRTGAVKEGDEV-VGSETRVKVVKNKV PPFRQAEFOILY ALRK ITGNIKNANCLVIF INOIRYKI GVWFG8PETTTGGNALKFYASVRLDIRRTGAVKEGDEV-VG8ETRVKVVRAKVAPPFROAEFOILY

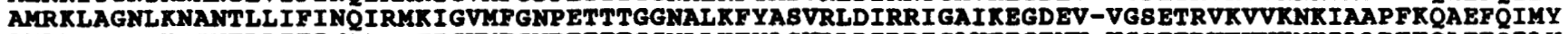

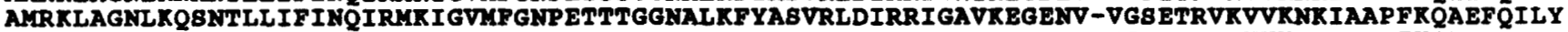
AMRKLAGNLXNSNTLLIF INOIRYXI GVYFGNP ETTTGGNALKFYASVRLDIRRIGSVKNGDEV-IGSETRVKVVKNKVAAPFKOAEFOIMY

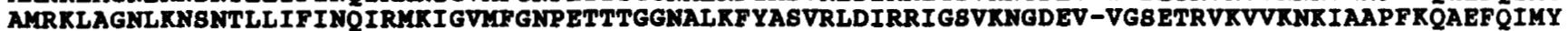

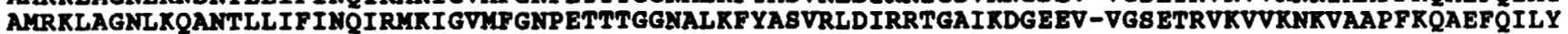
AYRKLTGNLKO SNCKCIFIYO IRYRI GVWFGNPETTTGGNALKFYASVRLDIRRTGSIKEGDEA-VGNETRIKVVRNKIAAPFROADTOILY ALRKLTANI RRTNTLVIF INOIRYKI GLYPGNPETTTGGNALKFYASVRLDIRRTGAIKKGDEV-TGSETRVKVVKNNVAPPFRLAEFDILY

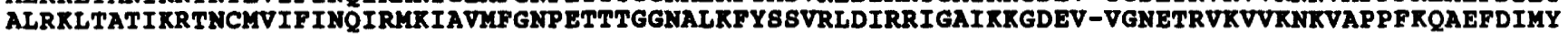
ALRKLTGTIKRTNCLVIFINOIRYR I GVMPGNPETTTGGNALKFY S8VRLDIRR IGSIRKNDEV-IGNETRVKVVKNKV8PPFREAIFDILY ALRNLTANI 8R8NTLVIFINÖIRYKI GVMYGSPETTTGGNALKFYASVRLDIRRIGAIRX8DEV-VGNDTRVKVVKNKVAPPFREAEFAIYY ALRKLTGAIXRTWTLVVPINQIRMXI GVMFGSPETTTGGNALKF YS SVRLDIRRTGSIKKGEEV-LGNETRVKVIKNKVAPPFRQAEPDILY ALRKLTGSV SR 8KT IVIFINOIRMRI GVUFGNPETTTGGNALKFYASVRYEIRRVGAIKDRDEV-VGNQTRVKVVKNKLAPPFKVVDFDIMY

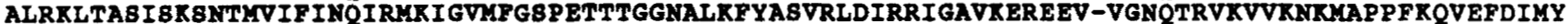

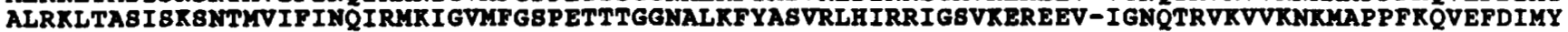

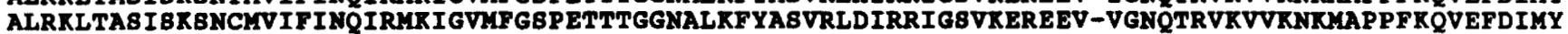
ALREI SGAINT SKTIAIFINOOIREKVGVYPGNPETTPGGRALRFYSSVRLEVRRAEOLKOGNDV-MGNRTKIKVVKNKVAPPFRTAEVDIMY AYRKYSGVI 8R8NVVAIF INO IREKV GVMFGNPETTPGGRALKFF 8SVRLEIRRAEAIKÖGSEM-IGIKSNVKVVRSKVAPPLKTAS IDIKY ALRKLTSAVBRTRTTCIF INQLREKI GVMFGUPETTTGGNALKFYASVRLDIRGSQQIRDGEEV-IGXOTKVKVVKNKVAPPFRKAEFDIMF ALRKIAGMYGR SCTVIFLNOLROKI GI SYGNP EVTTGGTALKF YASVRLDIRRIOTLRKGSEGEFGIRAKVKVAKNKVAPPFRIAEFDI IF ALRKITGNIGRSGCTVIF INQLLQRI GVTYGSPETTTGGNALKFYASVRLDIRRIQTLRKGTD-EFGNRVKVKVAKNKVAPPFR IAEFDI IF

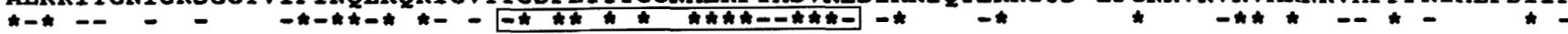

\section{GKGI YRNGEI IDLGVQLGLLEKSGAWY SYQGSRIGQGKANAAKFLEDNPEVAAAVEKSIRDQLLAAPASARPAALADEPADADLDY} GXGI YRTGEI IDLGVOLGLVERSGAWYSYQGSKIGQGKANAAKYLEDNPEIGSVLEKTIRDQLLAKSGPVRADAEEVADAEAD

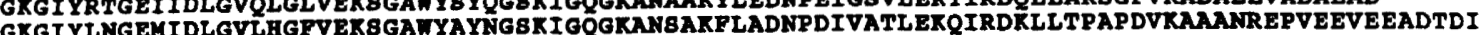
GKOT GEGINSRGELVDLGVRHKMIEKAGAWYSYNGEKIGQGRANACFWKRPATAKEIEKKVRELLLSNPNGTPDF SVDDSEGVAETNEDF GEGINFYGELVDLGVRERLIEKAGAWY YYGERIGQGRANATAWLRDNPETAKEIEKKVRELLLSNPNBTPDFSVDDSGVAETNEDF GEGINTYGEL IDLGVKHRLVEKAGAWY SYNGERIGQGRANATNYLKEHPENYNELNTKLREKLLNHAGEFTSAADFAGEESDSDADDTKE GEGINTFGELIDLGVKRKLVEKAGA YSYNGEKIGQGKANACNFLKENSLVKATKMFNGC

GEG

GQG

GEGI IREGEIIELGVWLRLIEKAGAWYSYKGEKIGQGRDNREYRKEHKEYAIEIENKVRENOGIVSRAATFPASEAEDGE

GSG I SREGEIIDLGVQANVWDRBGAWY SYBGNRIGQGKDNVREYLKEHKEYAIEIENKVRENQGIVSRAATF PASEAEDGE

GEGISRQGEI DLGVQATIVEKSGATY Y YQGHRIGQGKDNARQYLKVHP ELAANIEQRIRAAAAGHPLAFAEEVESPQRBAS

GEGISWEGELIDIGVKWDIINR SGAWY SYNGARIGQGRDNVR WLKENPEISDEIDAKIRALNGVEWHITEGTQDETDGERPEE

GEGISWEGLIDIGVN INR SGAWF SYNSTRTGOGRENAKOFLRDNPANAAEI EGAIRONAGLISEALAAVPDLDGTPVAE

GEGISKMGELIDLGVANVESG WF SYNSORLGOGRENARTFLRDNPDLAREIELSLRONAGLIADRFLQWGGPDPDDGDGDATAEM

GEGVSKTGELVDLGVXAGIVEKSGAWF SYNSORLGQGGENAKTFLRDNPDLAREIELALRENAGL IADRFLQNGGPDADDGDGADM

GEGVSKTGELIDLGVIAGIVERBGAWP SYNBQRLGQGRENAKLFLRENPELLREI ETALRQNAGL IADRFLENGGPESDGDEAADY GEG ISREGEI IDLGTELDIVOKBGSWY YYEEERLGQGRENAROFLKENKDIMLMI QEQIREHYGLDNNGVVQQQAEETQEELEFEE GTG SRSGEVL SVELNIVN SGA WNIGEERLGOGRDNAROYLEDKPELLNELEKKVRTHFKLTK

GTGISR

GEGI IHSGEI IDLGADLGIIRSGS YYY

GXGI BRVGCMLDLAEOTGVITRKGAWYSYEGDNIAQGRDNAVXYLEENPDVAATTQRVREKLDKGAVVSANSVAKANEEDEEDVDLDEEE

Fig. 5. Multiple alignment of RecA proteins from eubacterial species (codes as in Fig. 4). Perfectly conserved positions are marked by asterisks and positions with similar residues (S-T-A; L-V-I-M; K-R; D-E; Q-N; T-S; F-Y-W) occurring in all sequences are indicated

by dashes. Boxed consensus sequences are discussed in the text.

However, in both reports the aforementioned conserved stretches are not covered by the enzymically amplified regions.

Construction and characterization of a rec $A$ mutant

The following strategy was used to inactivate the $\operatorname{rec} A$ gene of $P$. fluorescens OE 28.3. The $3 \mathrm{~kb}$ HindIII fragment was cloned in the unique HindIII site of pSUP102. The resulting tetracycline-sensitive clone (pFAJ2058) contained two BbrPI sites, one of which was in the Pseudomonas DNA (Fig. 2). Therefore, the kanamycin resistance cassette, excised from pUKA800 as a $1.25 \mathrm{~kb}$ HindII fragment, was blunt-ligated to partially BbrPI-digested pFAJ2058. The recombinant suicide plasmid (pFAJ2059), with the cassette inter- rupting the $r e c A$ gene at its unique $B b r$ PI site, was mobilized from $E$. coli $\mathrm{S} 17-1$ into P. fluorescens OE 28.3. Kanamycin-resistant transconjugants were screened for loss of vector-mediated chloramphenicol resistance to trace putative mutants that had exchanged their wildtype gene with the inactivated $\operatorname{rec} A$ by a double crossover event. For one such strain (FAJ2025), this was unequivocally demonstrated by Southern hybridization experiments with specific probes for $\operatorname{rec} A$, for the kanamycin cassette, and for the suicide vector used (results not shown).

The rec $A$ mutant of $P$. fluorescens OE 28.3 produced somewhat smaller colonies on solid medium and had a slightly increased doubling time in liquid TSB medium (102 min as compared to $89 \mathrm{~min}$ for the wild-type strain). A similar effect on growth rate was reported for rec $A$ 


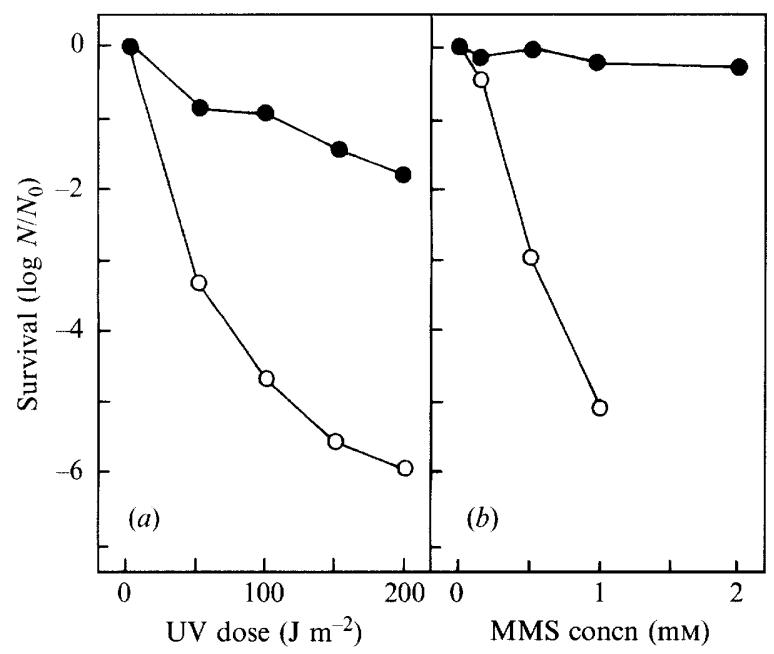

Fig. 6. Sensitivity of $P$. fluorescens OE $28.3(-)$ and its $r e c A$ mutant FAJ2025 (O) to UV irradiation $(a)$ and MMS $(b)$. The fraction of surviving cells $\left(N / N_{0}\right)$ was determined for each treatment from the number of residual cells $(N)$ and the number of cells initially applied $\left(N_{0}\right)$. Values represent means of three determinations. At 2 mM-MMS, no surviving cells of FAJ2025 were detectable.

mutants generated for Rhizobium meliloti and $R$. leguminosarum (Selbitschka et al., 1991).

Strain FAJ2025 was distinctly more sensitive to MMS and substantially less resistant to UV irradiation as compared to the parent strain (Fig. 6), which is typically observed for recA mutants (Miller \& Kokjohn, 1990).

The relative recombinational activity of the $\operatorname{rec} A$ mutant was estimated by determining the integration frequency of the tetracycline resistance marker from the suicide plasmid pSUP102 carrying a large Pseudomonas insert. Frequencies were reduced from $9 \times 10^{-4}$ in the wild type strain to $5 \times 10^{-9}$ in the mutant in case of pFAJ2083 ( $4 \mathrm{~kb}$ insert), and from $5 \times 10^{-4}$ to $4 \times 10^{-9}$ when using pFAJ2084 (5 kb insert). These data clearly demonstrate that the recA mutant FAJ2025 is severely impaired in performing homologous recombination.

The recombination-deficient $P$. fluorescens mutant will be useful for further genetic experiments that require a stable maintenance of introduced, plasmid-borne genes to study their involvement in processes such as root adhesion, antibiotic-mediated antagonism of phytopathogens or direct plant growth promotion.

Note added in proof. The deduced amino acid sequence for the Lactococcus lactis subsp. lactis RecA [Duwat, P., Ehrlich, S. D. \& Gruss, A. (1992). Use of degenerate primers for polymerase chain reaction cloning and sequencing of the Lactococcus lactis subsp. lactis recA gene. Applied and Environmental Microbiology 58, 2674-2678] deviates from the $\mathrm{N}$-terminal consensus sequence presented in this paper at two positions ( $\mathrm{L}$ instead of $\mathrm{Q}$ or $\mathrm{K}$, and $\mathrm{L}$ instead of $\mathrm{V}$ or I).

The authors wish to thank Dr T. Nakazawa (Yamaguchi University School of Medicine, Japan) for kindly providing plasmid pKN3. We are also grateful to D. Thoelen and T. Van de Putte who were involved in this work as undergraduate students. R. D.M. is a Research Associate with the Nationaal Fonds voor Wetenschappelijk Onderzoek (Belgium). This research was supported by a grant from the Onderzoeksfonds K. U. Leuven (OT/90/24).

\section{References}

BAIROCH, A. (1991). PROSITE: a dictionary of sites and patterns in proteins. Nucleic Acids Research 19, 2241-2245.

Barbé, J., Fernandez de Henestrosa, A. R., Calero, S. \& Gibert, 1. (1991). Chromogenic method for rapid isolation of rec A-like mutants of Gram-negative bacteria. Journal of Bacteriology 173, 404 406.

Calero, S., Garriga, X. \& Barbé, J. (1991). One step cloning system for isolation of bacterial lexA-like genes. Journal of Bacteriology 173. 7345-7350.

Cheo, D. L., Bayles, K.W. \& Yasbin, R.E. (1991). Cloning and characterization of DNA damage-inducible promoter regions from Bacillus subtilis. Journal of Bacteriology 173, 1696-1703.

DAvis, E. O., SEDGWICK, S. G. \& COLSTON, M. J. (1991). Novel structure

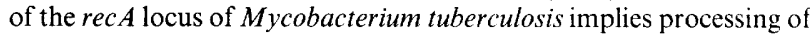
the gene product. Journal of Bacteriology 173, 5653-5662.

De Mot, R. \& Vanderleyden, J. (1991). Purification of a rootadhesive outer membrane protein of root-colonizing Pseudomonas fluorescens. FEMS Microbiology Letters 81, 323-328.

De Mot, R., Proost, P., Van Damme, J. \& Vanderleyden, J. (1992). Homology of the root adhesin of Pseudomonas fluorescens OE 28.3 with porin F of $P$. aeruginosa and $P$. syringae. Molecular and General Genetics 231, 489-493.

Deretic, V., Konyecsni, W.M., Mohr, C.D., Martin, D.W. \& HiBLER, N. S. (1989). Common denominators of promoter control in Pseudomonas and other bacteria. Biotechnology 7, 1249-1254.

Duwat, P., Ehrlich, S. D. \& Gruss, A. (1992). A general method for cloning rec $A$ genes of Gram-positive bacteria by polymerase chain reaction. Journal of Bacteriology 174, 5171-5175.

DYBVIG, K. \& WoODARD, A. (1992). Cloning and DNA sequence of a mycoplasmal recA gene. Journal of Bacteriology 174, 778-784.

Dybvig, K., Hollingshead, S. K., Heath, D. G., Clewell, D. B., Sun, F. \& WoOdard, A. (1992). Degenerate oligonucleotide primers for enzymatic amplifications of $\operatorname{rec} A$ sequences from Gram-positive bacteria and mycoplasmas. Journal of Bacteriology 174, 2729-2732.

FAVRE, D. \& VIRET, J.-F. (1990). Nucleotide sequence of the rec $A$ gene of Bordetella pertussis. Nucleic Acids Research 18, 4243.

Fernandez de Henestrosa, A. R., Calero, S. \& Barbé, J. (1991). Expression of the recA gene of Escherichia coli in several species of Gram-negative bacteria. Molecular and General Genetics 226. 503-506.

Frischauf, A. M., Murray, N. \& Lehrach, H. (1987). Lambda phage vectors - EMBL series. Methods in Enzymology 153, 103-115.

FrüH, R., Watson, J.M. \& HaAs, D. (1983). Construction of recombination-deficient strains of Pseudomonas aeruginosa. Molecular and General Genetics 191, 334-337.

FyFE, J.A.M. \& DAVIES, J.K. (1990). Nucleotide sequence and expression in Escherichia coli of the recA gene of Neisseria gonorrhoeae. Gene 93, 151-156.

Ghosh, S. K., Biswas, S. K., Paul, K. \& Das, J. (1992). Nucleotide and deduced amino acid sequence of the recA gene of Vibrio cholerae. Nucleic Acids Research 20, 372.

Gomelsky, M., GaK, E., Chistoserdov, A., Bolotin, A. \& Tsygankov, Y.D. (1990). Cloning, sequence and expression in Escherichia coli of the Methylobacillus flagellatum rec A gene. Gene 94, 69-75. 
Goodman, H. J. K. \& Woods, D. R. (1990). Molecular analysis of the Bacteroides fragilis recA gene. Gene 94, 77-82.

Higgins, C. F., Hiles, I. D., Whalley, K. \& Jamieson, D. J. (1985). Nucleotide binding by membrane components of bacterial periplasmic binding protein-dependent transport systems. EMBO Journal 4, 1033-1040.

LOCKETT, T.J. (1990). A bacteriophage lambda DNA purification procedure suitable for the analysis of DNA from either large or multiple small lysates. Analytical Biochemistry 185, 230-234.

Lugtenberg, B. J. J., DE Weger, L.A. \& BennetT, J.W. (1991). Microbial stimulation of plant growth and protection from disease. Current Opinion in Biotechnology 2, 457-464.

Martínez-Salazar, J. M., Romero, D., DE Lourdes Girard, M. \& DÁvILA, G. (1991). Molecular cloning and characterization of the recA gene of Rhizobium phaseoli and construction of recA mutants. Journal of Bacteriology 173, 3035-3040.

Michiels, J., Vande BroeK, A. \& Vanderleyden, J. (1991). Molecular cloning and nucleotide sequence of the Rhizobium phaseoli recA gene. Molecular and General Genetics 228, 486-490.

Miller, R.V. \& KoKJOHN, T.A. (1990). General microbiology of rec $A$ : environmental and evolutionary significance. Annual Review of Microbiology 44, 365-394.

Nakazawa, T., Kimoto, M. \& ABe, M. (1990). Cloning, sequencing and transcriptional analysis of the rec $A$ gene of Pseudomonas cepacia. Gene 94, 83-88.

RocA, A.I. \& Cox, M.M. (1990). The RecA protein: structure and function. CRC Critical Reviews in Biochemistry and Molecular Biology 25, 415-456.

Sano, Y. \& Kageyama, M. (1987). The sequence and function of the
recA gene and its protein in Pseudomonas aeruginosa PAO. Molecular and General Genetics 208, 412-419.

Sambrook, J., Fritsch, E.F. \& Maniatis, T. (1989). Molecular Cloning. A Laboratory Manual, 2nd edn. Cold Spring Harbour, NY: Cold Spring Harbor Laboratory.

Selbitschka, W., Arnold, W., Priefer, U. B., Rottschärler. T.. SCHMidT, M., Simon, R. \& PüHLER, A. (1991). Characterization of recA genes and recA mutants of Rhizobium meliloti and Rhizohium leguminosarum biovar viciae. Molecular and General Genetics 229. 86-95.

Simon, R., Priefer, U. \& Pühler, A. (1983). A broad host range mobilization system for in vivo engineering: transposon mutagenesis in Gram-negative bacteria. Biotechnology 1, 748-751.

Tolmasky, M.E., Gammie, A.E. \& Crosa, J.H. (1992). Characterization of the recA gene of Vibrio anguillarum. Gene 110, 41 48.

Venkatesh, T. V.\& Das, H. K. (1992). The Azotobacter vinelandii rec A gene: sequence analysis and regulation of expression. Gene 113. $47-53$.

WALKER, G.C. (1987). The SOS response of Escherichia coli. In Escherichia coli and Salmonella typhimurium. Cellular and Molecular Biology, vol. 2, pp. 1346-1357. Edited by F.C. Neidhardt, J. L. Ingraham, K. B. Low, B. Magasanik, M. Schaechter \& H.E. Umbarger. Washington, DC: American Society for Microbiology.

Willis, D. K., Hrabak, E. M., Lindow, S.E. \& Panopoulos, N. J. (1988). Construction and characterization of Pseudomonas stringae recA mutant strains. Molecular Plant-Microbe Interactions 1, 80-86.

ZhaO, X. J. \& MCEntee, K. (1990). DNA sequence analysis of the rec A genes from Proteus vulgaris, Erwinia carotovora, Shigella flexneri and Escherichia coli B/r. Molecular and General Genetics 222. 369-376. 